\title{
GLOBALISM OF EVOLUTIONISM*
}

\begin{abstract}
The phenomenon of globalization, which is well known in the economy, can nowadays be observed also in the area of science. It is based on the fact that more and more scientific disciplines are applying the same explanatory principle, namely the theory of evolution. Therefore, every development, including that of man, according to the pattern of genetic reproduction, takes place on the basis of natural selection. With psychological properties, mental abilities and social behaviours, which are eloquently referred to as "memes", it is as with genes: only those that are better, stronger, more capable of surviving will survive after accidental changes and only they will be passed on. In short, reproduction regulates and controls human behaviour. Such a way of thinking and explanation can be found today in many publications on sociobiology and evolutionary psychology. Even if they present many new details, they pay tribute to the old human desire to explain everything in a simple way, according to the same scheme. The same expectation towards science was expressed by E. Haeckel in the 19th century and J. Monod in the 20th century. However, when these two biologists explained man as a whole based on the theory of evolution, they admitted that they referred to philosophy, to which contemporary representatives of sociobiology and evolutionary psychology cannot or do not want to confess.
\end{abstract}

Keywords: globalization; evolutionism; sociobiology; evolutionary psychology; anthropology

1. Introduction. 2. Between the evolutionary description and the mechanism of evolution.

3. E. Haeckel's evolutionary monism. 4. J. Monod's evolutionism. 5. Between sociobiology and evolutionary psychology. 6. Conclusions.

* This article was originally published in Polish as: B. Hałaczek, Globalizm ewolucjonizmu, Studia Philosophiae Christianae 40(2004)2, 153-171. The translation of the article into English was financed by the Ministry of Science and Higher Education of the Republic of Poland as part of the activities promoting science - Decision No. 676/P-DUN/2019 of 2 April 2019. Translation made by GROY Translations. 


\section{INTRODUCTION}

The title formulation emphasizes the ubiquitous presence of evolutionism in the field of broadly understood anthropology, that is including, apart from natural anthropology, also the whole of this problem, which is usually placed within philosophical, cultural or even theological anthropology. Speaking of global evolutionism, the title emphasizes both the topicality of the subject matter under consideration and its dynamic character: the expansion of evolutionism into further and further areas of knowledge is similar to the better known and more visible expansion of economic and free market globalism ${ }^{1}$.

The expansion of evolutionism is undoubtedly supported by the ever-growing importance of biology in recent decades. However, it neither identifies with it nor is it its simple resultant. If that were the case, it would be possible to speak directly about the expansion of naturalism or about the globality of biology. The expression "evolutionism" defines the discussed phenomenon more correctly because it is not so much about an evolutionary description of the creation and development of man, but also and primarily about an evolutionary interpretation of human being, thinking and acting in their entirety. Therefore, if free market globalism is commonly defined as the global interweaving of economy, politics, law and culture, then the globalism of evolutionism in the field of anthropology can be defined as the interweaving of uniform and at the same time universal, on the basis of natural selection, explanations of the specific nature - both biological and behavioural, as well as psychological and social - of the human phenomenon in its entirety.

A fairly complete presentation of all these problems would require at least four chapters on separate topics: (1) Evolutionism in natural anthropology: from C. Darwin's theory of evolution to

1 Cf. Z. Bauman, Globalizacja. I co z tego dla ludzi wynika, PIW, Warszawa 2000; Globalopolis. Kosmiczna wioska. Szanse i zagrożenia, ed. R. Borkowski, PAX, Warszawa 2003; Duchowość współczesnego człowieka w świetle globalizacji i edukacji, ed. S. Urbański, Wydawnictwo UKSW, Warszawa 2003; Globalizacja a tożsamość, ed. J. Zdanowski, Askon, Warszawa 2003. 
E. Haeckl's evolutionism; (2) Evolutionism in philosophical and cultural anthropology: from evolutionary anthropology to evolutionary theory of cognition by K. Lorenzo, G. Vollmer, F. M. Wuketitsa; (3) Evolutionism in sociology: from evolutionary theory of cognition to sociobiology of E. O. Wilson and evolutionary monism of R. Dawkins; (4) Evolutionism in psychology: from sociobiology to extreme and moderate evolutionary psychology.

The entirety of such a study clearly exceeds the limits and possibilities of this article. Therefore, it will be limited to the historical, methodological and emotional background of each of the chapters mentioned above, that is it will focus on the genesis and some cognitive and psychological conditions of the monistic evolutionary explanations.

\section{BETWEEN THE EVOLUTIONARY DESCRIPTION AND THE EVOLUTIONARY MECHANISM}

It seems quite certain that, as a result of the data obtained from the observation of fauna in the Galapagos Islands, already since 1836, Charles Darwin was convinced that the concept of species stability must be rejected as erroneous and replaced by the concept of evolutionary development of living organisms. His biographers are still haunted by the question why he waited to publish his research and beliefs for so long, that is over 20 years? Today, the most probable reason for this delay is assumed to be his willingness to show the causes of evolutionary mutability, that is his willingness to answer the "why?" of evolution. However, Darwin obtained those only from the content of the terms "struggle for existence", "natural selection" and "selection", which he gained after intense reflection on the observed facts ${ }^{2}$.

The evolutionary description consists in and ends with a chronological and morphological ordering of the material. Phylogenetic sequences established on this basis are a consistent extrapolation, although with a certain admixture of hypotheticality. In spite of their

2 T. P. Weber, Darwin und die Anstifter. Die neuen Biowissenschaften, DuMont, Köln 2000 . 
hypothetical complements, they fall within the scope of evolutionary description as they still remain on the "how" dimension of evolution. However, all attempts to answer the "why" of such a course of action lie outside the scope of this dimension. In such a case, one should speak plainly only about evolutionary hypotheses or models, and not about the theory of evolution. In the name of the terminological order, one should only talk about evolution in the first case, while in the second case - about revolutionism. However, the dividing line between the two terms is blurred because the answers to "why" are often presented as answers to "how". And it is this possibility that is probably the strongest foundation of any evolutionism ${ }^{3}$.

On the margins of the above distinction of questions, it should be reminded that it is definitely a past belief that this very difference of questions marks the boundary between natural and philosophical anthropology. In the past, it was claimed that only the first one asks about "how", that is about the phenomenally perceptible qualities of man, while the second one asked about "what" and "why", that is about the so-called deep causality of a human being. In the meantime, however, it has become clear that a biologist is also allowed to legitimately ask questions "what?" and "why?". Ernst Mayr devotes three separate chapters (seventh, eighth and ninth chapter) of his latest book to these very questions. Darwin's theory is discussed in a chapter that is of vital importance to our discussion, entitled: Questions: "Why?"the evolution of organisms. Within its framework, he draws particular attention both to the ambiguity of the term "evolution" and to the fact that "in evolutionary biology, broad generalizations ... are rarely true".

With such a title and statement, Ernst Mayr only briefly expresses what his contemporary scientific methodologists Thomas

3 J. Stepan, Fakt ewolucji?, in: Człowiek wobec wyzwań racjonalności, ed. A. Kiepas, Uniwersytet Śląski, Katowice 2002.

4 E. Mayr, To jest biologia. Nauka o świecie ożywionym, transl. J. Szacki, Prószyński i S-ka, Warszawa 2002, 160. 
S. Kuhn ${ }^{5}$ and Karl R. Popper ${ }^{6}$ comprehensively discussed and proved, namely that every scientific theory is a kind of answer to the question "why", that none of them, however, has either the feature of full objectivity or the right to final truth. Their balanced judgment is crowned by Paul Feyerabend with perhaps too radical a warning but one, as it were, addressed to contemporary evolutionism, indicating that the whole of scientific objectivity must be reduced to subjectivity, while scientific truth must be reduced to the preference of a particular way of thinking ${ }^{7}$.

From the methodological analyses, so far carried out on different levels of scientific proceedings and cognition, two practical conclusions should be remembered when constructing and evaluating explanations that aspire to be theories: firstly, that the explanations offered by each theory can never enjoy the attribute of absolute certainty; and secondly, that each theory always explains merely a strictly defined and narrowed down phenomena and never the whole and arbitrarily chosen area of phenomena. Both of these reservations must be borne in mind when the mechanism of evolutionary explanations developed on the basis of specific organic groups is transferred to life in its entirety, in particular to the whole of the human phenomenon. Ernst Haeckel could not have known this in the second half of the nineteenth century, and today many proponents of the evolutionary interpretation of man in psychology and sociobiology do not want to remember it. Aware of both of these limitations, Jacques Monod provides in his work from $1970^{8}$, which he himself calls an essay on the limitations of biology and philosophy, an almost classic example of the methodological disharmony in which attempts to fully explain man within the framework of Darwin's theory of evolution become entangled.

5 T. Kuhn, Droga po Strukturze. Eseje filozoficzne z lat 1970-1993 i wywiad-rzeka z autorem słynnej „Struktury rewolucji naukowych”, transl. S. Amsterdamski, Sic!, Warszawa 2003.

6 K. Popper, Alles Leben ist Problemlösen. Über Erkenntnis, Geschichte und Politik, Piper, München 1995.

7 P. Feyerabend, Wissenschaft als Kunst, Suhrkamp, Frankfurt a. Main 1984, 77.

8 J. Monod, Le hasard et la necessite. Essai sur la philosophie naturelle de la biologie moderne, Seuil, Paris 1970. 


\section{E. HAECKEL'S EVOLUTIONARY MONISM}

Over time, the results of studies of comparative biology of living organisms confirmed not only the correctness of Carl Linnaeus' eighteenth-century classification linking man and monkeys as primates, but also the validity of Thomas Huxley's statement concerning man's close similarity to the chimpanzee and gorilla. For the first of Darwin's most ardent followers, Ernst Haeckel, the existence of this similarity became proof that the whole man, with his speech and consciousness, including morality and religion, is not different from great apes in terms of quality, but only in terms of complexity ${ }^{9}$. Haeckel speaks about this issue unambiguously, stating that: "The phylogeny of the human soul is inseparably intertwined with the organs of the human body, especially the brain ... . The psychological characteristics that distinguish us from other mammals are merely quantitative differences, not qualitative ones. The evolution of man provides psychology with the basis for monistic explanations and thus destroys this whole edifice of mysteries that was built on the dogma of the personal immortality of the human soul. The clarity of natural cognition definitively eliminates supernatural mythology"10. And the clarity of this cognition lies, in his conviction, in the fact that "the physiological functions of the body, usually called spiritual functions - or, in short, the soul - are controlled by the same physico-chemical mechanism as in other mammals"11.

Norbert Elsner very aptly and succinctly put forward Haeckel's views in his biographical introduction to Haeckel's correspondence with Frida von Uslar-Gleichen and her family, published in three volumes: "Haeckel did not follow the frameworks established for natural sciences. He transformed the biological theory of evolution into a worldview with an almost religious nature, crowned with the divine

9 E. Haeckel, Natürliche Schöpfungs-Geschichte. Gemeinverständliche Vorträge über die Entwicklungs-Lehre, Georg Reimer Verlag, Zehnte Auflage, Berlin 1902, 701-716.

10 Idem, Systematische Phylogenie der Wirbeltiere, Georg Reimer Verlag, Berlin 1895, 627.

11 Ibid, 625. 
qualities of goodness, truth and beauty"12. "In his opinion, the traditional distinction between soul and body should be abandoned for purely natural reasons and it should be recognized that human spirituality is also subject to evolutionary development. As a consequence, the concept of creation must be abandoned. Referring to Spinoza and Goethe ..., he accepted the universal spirituality of all nature, both animate and inanimate"13.

Haeckel drew his conviction of the validity of his arguments and his worldview from two sources. The first one was methodological in nature, as it was based on the thesis on the possibility of explaining all phenomena within the framework of causal determinism. The second one was more emotional and cognitive as it resulted from the desire to explain everything with one universal key, on the basis of one principle only.

Haeckel spoke of the strictly binding and all explanatory determinism on many pages of his extensive work, repeating in different words what he wrote already in 1868, in his Natural History of Creation: "We particularly emphasize that the internal causal relationships between all biological phenomena are exclusively mechanical. All explanations of the theory of evolution are also mechanical or 'physical'. This means that only causal causes (Causae efficientes) are taken into account, while intentional causes (Causae finales) must be excluded. This definitely justifies the legitimacy of philosophical monism and rejects the worldview of dualism and finalism". "The absolute confidence in the theory of evolution, also with regard to man ..., lies in the fact that as an inductive generalization of all natural phenomena ... it is a universal right and a logical necessity. The theory of the ape-pedigree of man is a detailed deductive conclusion from the general theory of evolution and is therefore also characterized by an absolute logical necessity"14.

In the presentation of such arguments, Haeckel constantly emphasized the important, almost indispensable role that philosophy

12 E. Haeckel, Das ungelöste Welträtsel. Frida von Uslar-Gleichen und Ernst Haeckel. (Briefe und Tagebücher 1898-1900), Wallstein Verlag, Göttingen 2000, 7.

13 Ibid, 41.

14 Idem, Natürliche Schöpfungs-Geschichte. Gemeinverständliche Vorträge über die Entwicklungs-Lehre, op. cit., 794 and 799. 
plays in them. "The naked, experiential facts", he wrote, "are merely raw building material which, without any deep reflection, without any intertwining with philosophy, does not create any science. ... Empirical data demand penetration, inner influence of philosophy, in order to create this unquestionable edifice of true, monistic science, that is an edifice called natural science" 15 .

Haeckl's philosophical-natural monism is not identical with either materialism, naturalism or spiritualism, as it is based on a thesis that one spirit brings everything to life and every manifestation of a spirit has a material basis. Haeckel considers it a mistake to expose the uniqueness of man: all the qualities that have so far distinguished man are in their rudiments also present in the animal world. In his opinion, this applies not only to bipedalism and brain structure, but also to speech, consciousness, morality and religion. Consequently, psychology should be the physiology of the spiritual life, while the register of superstitions should include, among other things, faith in the immortality of the human soul and in the existence of the personal God, the Creator ${ }^{16}$. Haeckel formulates the same conclusion in his other work as follows: "Providing psychology with a decidedly monistic basis, anthropogenesis destroys this giant edifice of mysteries built on the old dogma of the personal immortality of the human soul. Supernatural mythology must also in this case give way to clear natural cognition" ${ }^{\prime 17}$.

Haeckel linked the common physico-chemical determinism to the conviction that is it possible to provide uniform and absolutely certain explanations. In the spirit of this conviction, he wrote: "The theory of evolution not only gives a complete picture of the phenomenon of life, but also provides a satisfactory answer to all the 'whys' of this phenome-

15 Ibid, 782.

16 Idem, Der Monismus als Band zwischen Religion und Wissenschaft. Glaubensbekenntnis eines Naturforschers, vorgetragen am 9. Oktober 1892 in Altenburg beim 75jährigen Jubiläum der Naturforschenden Gesellschaft des Osterlandes, in: G. Heberer, Der gerechtfertigte Haeckel, Stuttgart 1968, 464-489; Idem, Über unsere gegenwärtige Kenntnis vom Ursprung des Menschen. Vortrag gehalten auf dem Vierten Internationalen Kongress in Cambridge am 26. August 1898, in: G. Heberer, Der gerechtfertigte Haeckel, op. cit., 403-421.

17 Idem, Systematische Phylogenie der Wirbeltiere, op. cit., 626. 
non"18. This all-encompassing answer is the law - in Haeckel's terminology the "theory" - of natural selection and, within it, the biogenetic law, which enables the reconstruction of phylogenetic development on the basis of available observations of ontogenetic development ${ }^{19}$. According to Haeckel, for the theory of evolution, this law is what the Newton's law of gravity became for Copernicus' heliocentrism, thus constituting a reliable and necessary tool for the cognition of nature ${ }^{20}$.

The extent to which Haeckel was fascinated by the possibility of having a "tool" that consistently explains the genesis and development of life is clearly illustrated by his numerous and almost unchanged, frequently re-issued human family trees. He did not hesitate to include forms in them with names invented at his desk, without any mention of their purely hypothetical character. And although most of his detailed remarks differed in content from that of sociobiology today, Haeckel is a precursor in his willingness to use homogeneous explanations and in his reluctance to reveal the burden of their hypothetical nature, and he should be a warning to contemporary sociobiologists. However, few of them realize that they are still or again merely following the thought paths set out by Haeckl as early as in the 19th century.

Such an accusation must not be made against this peculiar continuation of Haeckel's monism that Jacques Monod took up in the second half of the 20th century. And this is due to the fact that in his attempts to explain the whole of man within evolutionism, he was able to admit and indicate where and how he passed from the plane of objectivity of natural sciences to the plane of philosophy.

\section{J. MONOD'S EVOLUTIONISM}

For Monod, the primary duty and ultimate goal of all scientific research is to establish and explain the position of man in the universe. In his opinion, biology plays the leading role in the implementation

18 Idem, Natürliche Schöpfungs-Geschichte. Gemeinverständliche Vorträge über die Entwicklungs-Lehre, op. cit., 95.

19 Ibid, 303-309.

20 Ibid, 702. 
of this task. This is because biology, more directly than any other science, addresses the problems of "human nature". However, biology would be unable to do so if there was no theory of evolution. After all, this theory reaches the "essence" of life through the mechanism of inheritance that was deciphered within molecular genetics. Thus, molecular genetics today is the opportunity and foundation of the most profound cognition of living beings, including humans ${ }^{21}$.

The starting point for this cognitive process is to capture the characteristics that fundamentally distinguish living beings from inanimate objects. Such basic distinguishing features are, in Monod's opinion: (1) teleonomy, i.e. the purposeful construction of structures and directing their functions to the implementation of a pre-determined project; (2) autonomous morphogenesis, i.e. the self-determination of the growth process; and (3) reproductive invariance, i.e. the ability to invariably transmit genetic information.

Teleonomy itself is not yet a feature that distinguishes living beings, as it is also a characteristic of tools, machines constructed by man. However, what distinguishes living beings from all artifacts is their autonomous morphogenesis, that is the fact that they owe their creation and functioning to themselves and not to external forces. But the self-determination of structure and growth is also characteristic of crystals. In crystals, however, the source of this determinism is the grain of the same crystal, while the creation of a new living organism is decided by another living organism. Thus, the ability to invariably transmit genetic information from one organism to another is a crowning feature of the first two and it definitively characterizes living organisms.

If the mechanism of reproductive invariance worked flawlessly, that is the transmission of genetic information was inviolable, the preservation of life would be absolute and, consequently, there would be no evolution. In fact, however, the reproduction process entails various types of anomalies, its normal course being distorted by numerous mutations. A1though they are not subject to any regularity, they are "blind", pointless,

$21 \mathrm{~J}$. Monod, Le hasard et la necessite. Essai sur la philosophie naturelle de la biologie moderne, op. cit., 11. 
random, they are automatically transferred to proteins. And although most of them are lethal, harmful to the body, some of them turn out to be beneficial to the body under certain environmental conditions. These are immediately selected by the selection mechanism and preserved by the mechanism of reproductive invariance, thus introducing orderliness and targeted order in the cluster of random molecular connections. In Monod's words: "We are talking about incidental deformations, about changes caused by accident. They are merely a possible source of genetic information transformation, and therefore the only manager and controller of heredity. Thus, chance is the sole source of every novelty, it is the sole maker of the entire biosphere"22. Evolution is the produce of the convergence of a random disruption at the molecular level with an incidentally beneficial functioning of a modified organic structure.

The basis of the evolutionary process is the imperfection of the organism's self-preserving tendency, there are errors in the mechanism of replicative invariance. But the motor of evolution is natural selection. It makes an incidental novelty in genetic material a functionally beneficial novelty. This "makes" does not, after all, identify itself solely with the impact of the external environment on the body. Selection is a result of environmental factors and the internal aspirations of the organisms to consolidate and enhance their teleonomic performance, it couples the specific nature of the organism with its anatomical equipment. "Selection", Monod writes, "only allows those mutations that do not weaken but increase the teleonomic compactness of the body" ${ }^{23}$. In other words: the influence of external factors depends on the teleonomic advancement of a particular organism, a particular species. Thus, the internal factors of an organism or species determine, to some extent, the type and direction of selection to which they are subject.

The higher the degree of organization or development of individual organisms or entire species, the stronger the influence of the internal environment on the evolutionary process. And as this development progresses, the importance of ways of behaving in this development 
increases. Just as an incidental mutation, the incidental "choice" of a new way of behaving can increase the ability to adapt and develop, thus improving the teleonomic equipment of the organism, or the species. Selection forces first to affirm and then to favour beneficial forms of behaviour. This, in turn, gives preference to those structures which enable and facilitate such beneficial behaviours. Thus, the "invention" of a new way of behaviour may in a specific way shape the course of evolutionary development ${ }^{24}$.

The interdependence of structures and behaviours conditioning evolutionary development has led to the emergence of the ability to imagine, i.e. enabled non-visual perceptions, at a certain level of cerebral development. Thanks to it, the most developed beings of their time were able to recreate the experiences of the past and, on the basis of their internal experiences, anticipate future events and prepare for them in advance.

Specific practice confirmed and indicated the obvious advantages of this, although initially still primitive, ability to look to the future. Therefore, selection favoured the ability to anticipate the future and, under pressure from a number of negative experiences, it corrected and improved it. This, in turn, led to the further development of the central nervous system. The end result is a brain capable of predictions consistent with the outside world and the good of the species. This is how the harmony between the purely theoretical reasoning "from behind the desk" and the actual structure of external reality, which is often admired but sometimes misinterpreted today, came about. The logic of modern man is ultimately nothing more than a collection of experiences of the fossil man and his ancestors recorded in the brain ${ }^{25}$. The ability to imagine is the individual ability of particular individuals. As such, it is not yet capable of shaping social behaviour, but it is nevertheless an indispensable basis for this new achievement, that is symbolic speech. The opportunity to share one's own sensations and experiences, personally acquired and considered internal 
and external experience, with other individuals has had a decisive impact on changing social activities and behaviours. The ability of verbal communication was such an advantage for the first hominids that natural selection had to be interested in its further development. And by perfecting the ability of symbolic speech, it lead to the further development of the brain. Thus, speech has become a factor shaping both biological and behavioral evolution of man.

On the basis of the exceptional effectiveness of actions and behaviours created by the command of symbolic speech, with the simultaneous ignorance of the rules of functioning of the brain, created incidentally by way of selection, man came to the conclusion that he is fundamentally different from all other living beings, that he is a being that qualitatively exceeds the whole biosphere. This judgment gave rise to a conviction of a transcendent human nature resulting from it being endowed with an immaterial soul. However, this conviction is only an illusion, the dualism of body and soul is a mere illusion. But this illusion is so deeply rooted, almost genetically fixed, that without it, man cannot understand himself, nor can he live morally. A man should nevertheless know, Monod concludes, that he lives under an illusion, that he lives under a delusion ${ }^{26}$.

According to Monod, the same genesis and the same role in human life is played by another great dualism, namely the dualism of matter and spirit, dualism of the natural world and the world of ideas. The latter world is a subjective interpretation of causal relationships, it is a projection of deliberate human actions into the natural world. Its origins also date back to the birth of symbolic speech, that is to the beginnings of humanity. Equipped with the ability to speak but biologically defenseless group of human beings had to experience, every step of the way, that their strength is determined by their cooperative compactness. In order to preserve this compactness, for effective consolidation within individual human groups, it was necessary to clearly show the historical importance of the whole group and, at the same time, to have guidelines to mobilize individual members to fulfil their 
tasks. Such a unifying and mobilizing role was played by the sets of various principles, i.e. different kinds of myths, "encoded" in the outside world. The human species owes its survival, development, domination over its environment to them. Thus, although the mythical justification of man's position, privileges, and duties departs from the objective truth, their indispensability is anchored in human biology. In Monod's words: "Mythical and religious beliefs are, like all philosophical systems, the price that man pays for his existence" 27 .

The development of the world of ideas resulted in biological evolution no longer controlling the human world. Thanks to his knowledge, man freed himself from dependence on the laws of selection and took evolution into his own hands. Today, he lives not on the achievements of evolution, but on the achievements of knowledge. Unfortunately, Monod complains, in ethical issues he still refers to the biological past. After all, he continues to explain the fact and way of his existence on the basis of mythical ideology, as well as continues to seek a measure of objective ethical values in the external reality beyond. Unfortunately, the outside world does not have such a measure. It cannot have it because in the light of objective scientific data the whole life is merely a product of chance.

Scientific cognition does not provide man with any explanation for his existence or any objective, top-down standards of conduct. As an incidental product of blind evolution, man is not determined by any external factor and has to determine himself in the daily practice of actions and behaviours. Moreover, science also reminds us that the order of valuation is at a level that goes beyond the limits of objective cognition. Therefore, according to the directives of science, man only has this one option: to fully accept both his own contingency and his sole responsibility for ethical norms. The postulate of scientific objectivity requires man to take full responsibility for himself. Until he does so, he will live in the magical world of his ancestors, he will lie to himself about the existence of objective ethical norms, encoded outside of or beyond human reality. 
If top-down directives of conduct are not given to man, if he is to create them himself, than what can guarantee his assessments any relative but the highest possible correctness? Monod's answer is: although modern science knows that its cognition is not a direct source of evaluation, it is only on its basis that a person can achieve objective, or the least subjective evaluation. The postulate of objectivity demands that value judgements be based on cognition, so it only approves of the ethics of knowledge, the ethics of cognition. Therefore, its creator can only be a creature gifted with the ability of cognition - a human being. Monod concludes this line of reasoning with a proposal in which cognitive optimism is intertwined with existential pessimism: "Finally, modern man knows that, in the face of the immense indifference of the universe from which he accidentally emerged, he is left entirely on his own. Neither his destiny nor his duties have been written down anywhere. It is up to him alone what choice he makes: he can choose darkness and he can choose kingdom"28.

For Haeckel and Monod alike, man, with all his biological and psychological equipment, is a produce of evolution. As such, he is, to both of them, a creation of a blind chance, as he is merely a product of the beneficial convergence of randomly occurring organic changes with a blind determinism of natural selection. Consequently, both of them deny the existence of purposefulness external to the human being and explain its origin and operation by evolutionary determinism. For both of them, evolutionism is a consistent glorification of the objectivity of scientific cognition, although in Monod's case, it is not burdened with the apodictic confidence characteristic for Haeckel. It has revived again today, though without the nineteenth-century ideological aggressiveness, in the evolutionary sociobiology, while Monod's biology continues today, though with reduced methodological criticism, evolutionary psychology. It seems certain that today's intertwining views of sociobiology and evolutionary psychology are, in their basic construction, merely a more elaborate, more detailed argumentation enriched by Haeckel's and Monod's version of the philosophy of nature. 


\section{BETWEEN SOCIOBIOLOGY AND EVOLUTIONARY PSYCHOLOGY}

If sociobiology is defined as "the scientific study of the biological foundations of all forms of social behaviour" 29 , and evolutionary psychology as "a true synthesis of the contemporary principles of psychology and evolutionary biology" ${ }^{\prime 0}$, then it is already clear from the definitions themselves that it is impossible to draw clear-cut substantive boundaries between the two disciplines. This can be clearly confirmed, for example, by the quoted here and standard for evolutionary psychology work by David Buss. The author devotes several chapters precisely to the problem of human behaviour that sociobiology also speaks about in a similar way. Therefore, it seems reasonable to claim that evolutionary psychology is not only a chronological but also a thematic continuation of sociobiology. Both are related to the revolutionary theory of ethological cognition of the Konrad Lorenz school, although the quality of this relationship is controversial ${ }^{31}$.

This text deliberately distances itself from the - deserving of a more detailed analysis - issue of the type and degree of closeness of these links, and it does not take up the undoubtedly interesting discussion on the content-genetic or purely chronological relationship between sociobiology and ethology. Attention is focused entirely on the desire to show,

29 E. O. Wilson, O naturze ludzkiej, transl. B. Szacka, PIW, Warszawa 1988, 256.

30 D. M. Buss, Psychologia ewolucyjna, transl. M. Orski, Gdańskie Wydawnictwo Psychologiczne, Gdańsk 2001, 17.

31 Cf. e.g. E. O. Wilson, Sociobiology. The new Synthesis, Harvard University Press, Cambridge, 1975; Idem, Consilience. The Unity of Knowledge, Alfred A. Knopf, New York 1998; Idem, O naturze ludzkiej, op. cit.; D. P. Barash, Sociobiology and Behavior, Elsevier North-Holland, New York 1977; R. Dawkins, Samolubny gen, transl. M. Skoneczny, Prószyński i S-ka, Warszawa 1996; Idem, Ślepy zegarmistrz czyli jak ewolucja dowodzi, że świat nie został zaplanowany, transl. A. Hoffman, PIW, Warszawa 1994; R. Riedl, Biologie der Erkenntnis. Die stammesgeschichtlichen Grndlagen der Vernunft, Paul Parey, Berlin und Hamburg 1979; F. M. Wuketits, Biologische Erkenntnis, G. Fischer, Stuttgart 1983; Evolution, Ordnung und Erkenntnis, eds. J. A. Ott, G. P. Wagner, F. M. Wuketits, Paul Parey, Berlin - Hamburg 1985; Z. Łepko, Antropologia Konrada Lorenza, in: Z zagadnień filozofii przyrodoznawstwa i filozofii przyrody, vol. 13, eds. M. Lubański, S. W. Ślaga, Wydawnictwo ATK, Warszawa 1991, 157-280; A. Pobojewska, Biologiczne "a priori" człowieka a realizm teoriopoznawczy, Wydawnictwo Uniwersytetu Łódzkiego, Łódź 1996. 
even at the cost of certain simplifications, the community that combines sociobiology with evolutionary psychology. In particular, they are linked by a common starting point and a similar course of argumentation, and, consequently, also by close formal deficiencies and content errors.

Both disciplines start from a consistent conviction that it is possible to understand and explain the development and specific nature of man at the level of the theory of evolution, completely disregarding the common within this theory distinction between the course and mechanism of evolution. Consequently, in their entire argumentation, they are both based only on hypothetical assumptions about the mechanisms that control the course of biological evolution. Moreover, the arguments of both seem to be entangled in a similarly erroneous cycle: on the one hand, they explain the current ways of behaviour with evolutionary conditions, and on the other hand, they conclude from the observation of the current behaviour that the specific evolutionary conditions are indispensable.

The starting point of sociobiology and at the same time its formal bridge to evolutionary psychology is the individualization of natural selection. This allows the equipment and behaviour of specific individuals to be explained in the same way as the theory of evolution explains the origin and development of species, i.e. allowing the genes of specific individuals to be assigned the importance that the gene pool plays within the whole species. In turn, the starting point of evolutionary psychology and the bridge that connects it with sociobiology in terms of content is the concept of meme. It allows the knowledge acquired on the plane of biological evolution to be transferred to the plane of cultural evolution, as memes are attributed the same content and the same role as genes play in biology. Just as a gene is the unit of biological inheritance, the unit of cultural inheritance is imitation, that is a "meme": the shortened version of the Greek "mimem" in view of the "gene"32.

32 Cf.: S. Blackmore, The Meme Machine, University Press, Oxford 1999; Gene, Meme und Gehirne. Geist und Gesellschaft als Natur, eds. A. Becker et al., Suhrkamp, Frankfurt am Main 2003. 
The so-called memology, as referred to by its founders and users, can, formally and in terms of content, be treated as a classical pattern of thought circling in the name of obtaining uniformly simplified explanations. This circling is documented by the terminology itself: the cultural information conveyed through the ability of imitation is given the name meme to enable the attribution of what the gene makes and what the gene is: the bearer of heredity through replication and, at the same time, the driver of evolution through selection carried out in the dispersion of the incidental changeability. If, however, the starting point of the arguments is what is to be their final result, it is difficult to be surprised at the vagueness of the concepts underlying the respective reasoning. This is clearly demonstrated by some of Susan Blackmore's statements. Thus, for example, a "meme" is, according to her, information copied in the process of evolution, namely that which causes evolution, and at the same time information that can be copied, that is the subject of evolution. Her reasoning can serve as one of the many examples of such entangled and thus intricate arguments: "If ... imitation may guarantee the process of evolution, ... then the definitions of meme and imitation can be easily linked to each other by stating that a meme is everything that is transmitted by way of imitation and that memes are found everywhere that imitation takes place"33.

This kind of freedom in terms of the starting point and the complexity in the course of the argumentation is a sacrifice made by their authors in favour of the possibility of having a unified vision of human creation and development, however simplified. This target point of her argumentation is presented by S. Blackmore in the form of "meme theory" as follows: "The evolution of hominids reached a breakthrough point when our ancestors began to imitate each other, thus introducing this new replicator, that is a meme, into the world. The environmental changes caused by memes lead to gene selection, with the direction of the changes being determined by memetic selection. The numerous effects of such changes include such reorganization of the human brain

33 S. Blackmore, Evolution und Meme: Das menschliche Gehirn als selektiver Imitationsapparat, in: Gene, Meme und Gehirne, op. cit. 67-68. 
and speech organ that favoured the replication of better adapted memes" ${ }^{\text {"3 }}$. Such an "argument" probably deserves an articulate evaluation stating: sapienti sat! And it would be worth answering the question of whether and to what degree is the content of this argumentation new in conjunction with what J. Monod has already said about the contribution of imitation to the evolution of hominids.

However, with all its intellectual indigestion, the concept of memes has one indisputable merit: its very existence documents the insufficiency of purely genetic explanations offered by the original versions of sociobiology and evolutionary psychology in the form of the concept of a "selfish gene". It includes the reduction of living individuals, including the human being, to the role of a case or a vehicle, concerned only with the transmission of their own gene information, which is a peculiar continuation of the nineteenth-century naturalism and an up-to-date example of contemporary biologism in the interpretation of the human phenomenon.

Perhaps the awareness of this accusation is explained by the fact that the central role in the views and outlooks of sociobiology and evolutionary psychology is played by the issue of aggressive and sexual behaviour, i.e. behaviour with a clear domination of purely biological determination. Within and by means of these behaviours, there is indeed a lot of data to support and multiple examples to illustrate the thesis of natural selection on the effective survival of the best adapted individuals. But can the need for reproduction explain the whole array of human behaviours? Does it fully explain even just sexual behaviour in its entirety? So far, it has not even been possible to distinguish between what kind of behaviour this need actually causes and which behaviours are merely its hypothetical illustrations. The concept of global evolutionary explanations in sociobiology and evolutionary psychology has also failed to deal with many examples of human behaviour in which the procreative interest plays no role. Therefore, as such, it is unable to benefit from the previous achievements of the philosophy and methodology of sciences: not only is it not subject to falsification, but it does not even care about verification. 


\section{CONCLUSIONS}

The main idea of the above-mentioned arguments can be summarized in the following three points:

(1) In the second half of the nineteenth century, Ernest Haeckel presented his philosophical monism in the form of a necessity and possibility of replacing the explanations of religious faith with explanations of the theory of evolution. In the conviction that scientific explanations are rationally homogeneous and brutally correct, he eliminated teleonomic explanations for the benefit of the universal causal determinism, which also includes human beings in their entirety.

(2) At the beginning of the second half of the twentieth century, Jacques Monod made a similar attempt to explain the origin and development of the whole animated world, including man, on the basis of the theory of evolution. However, his evolutionism lacks the apodictic confidence characteristic of Haeckel's evolutionism, although, just as Heackel's evolutionism, it glorifies scientific cognition as the only instance of correct, rational explanations.

(3) The explanations offered today on the basis of this theory of evolution are being disseminated and transferred by sociobiology and evolutionary psychology to an ever wider range of phenomena. Within the framework of both these disciplines, the Haeckel's and Monod's philosophy of determinism and chance is continued and developed in detail. They differ from Haeckel's evolutionism in their lack of an anti-religious attitude, and from Monod's philosophy - in their lack of concern for the self-criticism that characterizes modern natural science. They are linked with Monod himself by a similar interpretation of religion as one of the factors facilitating man's survival, while with Monod and Haeckel, they have a similar tendency to explain the whole reality as simply and uniformly coherently as possible. They owe their popularity to this tendency, although the price they pay for it is a considerable lack of criticism. 


\section{BIBLIOGRAPHY}

Alles Leben ist Problemlösen. Über Erkenntnis, Geschichte und Politik, Piper, München 1995. Barash D. P., Sociobiology and Behavior, Elsevier North-Holland, New York 1977. Bauman Z., Globalizacja. I co z tego dla ludzi wynika, PIW, Warszawa 2000.

Blackmore S., The Meme Machine, University Press, Oxford 1999.

Buss D. M., Psychologia erwolucyjna, transl. M. Orski, Gdańskie Wydawnictwo Psychologiczne, Gdańsk 2001.

Dawkins R., Samolubny gen, transl. M. Skoneczny, Prószyński i S-ka, Warszawa 1996.

Dawkins R., Ślepy zegarmistrz czyli jak ewolucja dowodzi, że świat nie zostat zaplanowany, transl. A. Hoffman, PIW, Warszawa 1994.

Droga po Strukturze. Eseje filozoficzne z lat 1970-1993 i wyrwiad-rzeka z autorem stynnej „Struktury rewolucji naukowych”, transl. S. Amsterdamski, Sic!, Warszawa 2003.

Duchowość wspótczesnego cztowieka w świetle globalizacji i edukacji, ed. S. Urbański, Wydawnictwo UKSW, Warszawa 2003.

Evolution, Ordnung und Erkenntnis, eds. J. A. Ott, G. P. Wagner, F. M. Wuketits, Paul Parey, Berlin - Hamburg 1985.

Feyerabend P., Wissenschaft als Kunst, Suhrkamp, Frankfurt a. Main 1984.

Gene, Meme und Gehirne. Geist und Gesellschaft als Natur, eds. A. Becker et al., Suhrkamp, Frankfurt am Main 2003.

Globalizacja a tożsamośc, ed. J. Zdanowski, Askon, Warszawa 2003.

Globalopolis. Kosmiczna wioska. Szanse i zagrożenia, ed. R. Borkowski, PAX, Warszawa 2003.

Haeckel E., Das ungelöste Welträtsel. Frida von Uslar-Gleichen und Ernst Haeckel. (Briefe und Tagebücher 1898-1900), Wallstein Verlag, Göttingen 2000.

Haeckel E., Der Monismus als Band zwischen Religion und Wissenschaft. Glaubensbekenntnis eines Naturforschers, vorgetragen am 9. Oktober 1892 in Altenburg beim 75 jährigen Jubiläum der Naturforschenden Gesellschaft des Osterlandes, in: G. Heberer, Der gerechtfertigte Haeckel, Stuttgart 1968, 464-489.

Haeckel E., Natürliche Schöpfungs-Geschichte. Gemeinverständliche Vorträge über die Entwicklungs-Lehre, Georg Reimer Verlag, Zehnte Auflage, Berlin 1902.

Haeckel E., Systematische Phylogenie der Wirbeltiere, Georg Reimer Verlag, Berlin 1895. Haeckel E., Über unsere gegenwärtige Kenntnis vom Ursprung des Menschen. Vortrag gehalten auf dem Vierten Internationalen Kongress in Cambridge am 26. August 1898, in: G. Heberer, Der gerechtfertigte Haeckel, Stuttgart 1968, 403-421. 
Łepko Z., Antropologia Konrada Lorenza, in: Z zagadnień filozofii przyrodoznawstwa i filozofii przyrody, vol. 13, eds. M. Lubański, S. W. Ślaga, Wydawnictwo ATK, Warszawa 1991, 157-280.

Monod J., Le hasard et la necessite. Essai sur la philosophie naturelle de la biologie moderne, Seuil, Paris 1970.

Pobojewska A., Biologiczne "a priori" cztowieka a realizm teoriopoznawczy, Wydawnictwo Uniwersytetu Łódzkiego, Łódź 1996.

Riedl R., Biologie der Erkenntnis. Die stammesgeschichtlichen Grndlagen der Vernunft, Paul Parey, Berlin und Hamburg 1979.

Stepan J., Fakt ewolucji?, in: Cztowiek wobec wyzwań racjonalności, ed. A. Kiepas, Uniwersytet Śląski, Katowice 2002.

To jest biologia. Nauka o świecie ożywionym, transl. J. Szacki, Prószyński i S-ka, Warszawa 2002.

Weber T. P., Darwin und die Anstifter. Die neuen Biowissenschaften, DuMont, Köln 2000.

Wilson E. O., Consilience. The Unity of Knowledge, Alfred A. Knopf, New York 1998.

Wilson E. O., O naturze ludzkiej, transl. B. Szacka, PIW, Warszawa 1988.

Wilson E. O., Sociobiology. The new Synthesis, Harvard University Press, Cambridge, 1975 .

Wuketits F. M., Biologische Erkenntnis, G. Fischer, Stuttgart 1983.

Bernard Hałaczek

DOI: $10.21697 /$ spch.2020.56.S2.06 